\title{
PERLINDUNGAN HUKUM TERHADAP ANAK KORBAN KEJAHATAN SEKSUAL DALAM PERSPEKTIF HUKUM POSITIF DAN ISLAM
}

\author{
Didi Sukardi \\ Fakultas Syariah dan Ekonomi Islam \\ IAIN Syekh Nurjati Cirebon \\ Jl. Perjuangan By Pass Sunyaragi Cirebon \\ Email : didisukardimubarrak@gmail.com
}

\begin{abstract}
Abstrak
Kasus kejahatan seksual terhadap anak terjadi hampir di seluruh daerah di Indonesia. Dalam Undang-Undang Nomor 23 Tahun 2004 Tentang Perlindungan Anak jo. Undang-Undang Nomor 35 Tahun 2014 Tentang Perubahan Atas Undang-Undang Nomor 23 Tahun 2004 Tentang Perlindungan Anak jo Peraturan Pemerintah Pengganti Undang-Undang Nomor 1 Tahun 2016 Tentang Perubahan Kedua Atas Undang-Undang Nomor 23 Tahun 2004 Tentang Perlindungan Anak disebutkan bahwa bagi pelaku tindak pidana kekerasan seksual maka dipidana dengan pidana penjara dan pidana denda. Selain itu juga diberikan pidana tambahan berupa pengumuman identitas pelaku, kebiri dan pemasangan alat detektif elektronik. Pidana penjara ditujukan bagi pelaku agar pelaku jera untuk tidak mengulangi kembali perbuatannya, sedangkan pidana denda dibayarkan kepada negara. Dari ketiga undang-undang tersebut ternyata perlindungan bagi anak korban tindak pidana seksual tidak terakomodir. Larangan melakukan perzinahan ada dalam Qur'an: Al-Israa' ayat 32. Hukuman zina dikenakan kepada kedua belah pihak (laki-laki dan perempuan) sedangkan untuk hukuman perkosaan (kejahatan seksual) dikenakan kepada pelakunya.
\end{abstract}

Kata Kunci : Pelindungan, Hukum, Anak, Kejahatan, Seksual

\begin{abstract}
Cases of sexual crimes against children occur almost in all regions in Indonesia. In Law Number 23 Year 2004 on Child Protection jo. Law Number 35 Year 2014 About Amendment To Law Number 23 Year 2004 Concerning Child Protection jo Government Regulation In Lieu of Law Number 1 Year 2016 About The Second Amendment To Law Number 23 Year 2004 Concerning Child Protection mentioned that for actor The criminal of sexual violence shall be subject to imprisonment and a fine of a fine. It is also provided with additional criminal in the form of identity announcement of the perpetrator, and the installation of electronic detective equipment. The imprisonment is intended for the perpetrators to deter the offender from repeating his actions, while the fine is paid to the state. Of the three laws, the protection for child victims of sexual crime is not accommodated. The prohibition on committing adultery is in the Qur'an : Al-Israa 'verse 32. The penalty of adultery is imposed on both sides (male and female) while for the punishment of rape (sexual crimes) is imposed on the perpetrators.
\end{abstract}

Keywords: Protection, Law, Child, Crime, Sexual 



\section{A. PENDAHULUAN}

Indonesia telah meletakan dasar dan tujuan didirikannya Negara Republik Indonesia, yaitu melindungi segenap Bangsa Indonesia dan seluruh tumpah darah Indonesia, dan untuk memajukan kesejahteraan umum, mencerdaskan kehidupan bangsa dan ikut melaksanakan ketertiban dunia berdasarkan kemerdekaan, perdamaian abadi dan keadilan sosial. Dalam batang tubuh Undang-Undang Dasar 1945 Amandemen Kedua, Pasal 28-B ayat (2) menyatakan bahwa setiap anak berhak atas kelangsungan hidup, tumbuh dan berkembang serta berhak atas perlindungan dari kekerasan dan diskriminasi. Sedangkan Pasal 28-C ayat (2) juga menyatakan bahwa setiap anak berhak mengembangkan diri melalui pemenuhan kebutuhan dasarnya. Hal tersebut menunjukkan bahwa Negara Indonesia mengakui hak-hak dasar anak, seperti hak kelangsungan hidup, tumbuh kembang dan mendapatkan perlindungan, merupakan hal penting yang harus diprioritaskan dalam upaya pemenuhan, baik berupa kebijakan maupun pelayanan. Komitmen Bangsa Indonesia untuk mewujudkan kesejahteraan umum dan mencerdaskan kehidupan bangsa sangat sejalan dengan komitmen masyarakat global untuk membangun dan mewujudkan masa depan tanpa beban penderitaan secara psikis maupun fisik atas kejahatan seksual yang anak terima.

Indonesia merupakan salah satu negara yang meratifikasi Konvensi Perserikatan BangsaBangsa (PBB) tentang Hak-hak Anak, melalui Keputusan Presiden (Keppres) Nomor 36 tanggal 25 Agustus 1990. Dengan diratifikasinya konvensi tersebut, seharusnya secara hukum negara berkewajiban melindungi dan memenuhi hak-hak anak, baik sosial, politik, budaya dan ekonomi. ${ }^{1}$

$$
\text { Namun, kenyataannya }
$$
negara masih belum mampu memenuhi kewajiban untuk memenuhi hak-hak anak. Salah satu permasalahan yang sampai saat ini masih kerap terjadi adalah kejahatan seksual terhadap anak. Selain melanggar hak-hak anak, keberadaan korban seksual anak ini juga dapat membawa dampak buruk kepada anak itu sendiri baik secara psikis maupun fisik, bahkan dikhawatirkan dapat mengganggu masa depan

\footnotetext{
${ }^{1}$ Hardius Usman dan Nachrowi Djalal Nachrowi, Pekerja Anak di Indonesia: Kondisi, Determinan dan Eksploitasi (Jakarta: Grasindo, 2004), Hal. 1
} 
anak-anak yang seharusnya mendapatkan kehidupan yang lebih baik.

Pembenahan kondisi korban kejahatan seksual terhadap anak merupakan suatu kebutuhan terutama bagi bangsa Indonesia. Korban kejahatan seksual terhadap anak harus mendapat perhatian penuh pemerintah dan perlu dijadikan salah satu prioritas pembangunan. Saat ini negara-negara maju semakin memperhatikan kesejahteraan dan kehidupan anak. Meskipun banyak kekhawatiran yang muncul, permasalahan korban kejahatan seksual terhadap anak di Indonesia ternyata tidak dapat disikapi dengan kompensasi dan restitusi untuk korban kejahatan seksual yang kurang berpihak pada anak (korban).

Fakta pada saat ini perhatian dalam hal perlindungan terhadap hak koban kejahatan seksual sangat kecil jika dibandingkan dengan perhatian yang selalu dicurahkan terhadap perlindungan hak asasi para pelaku kejahatan. Di dalam rumusan KUHAP ada peraturan pelaksanaannya, proses penanganan kejahatan mulai dari penyidikan, penuntutan, peradilan bahkan hakhak para korban hampir tidak mendapat perhatian secara profesional. Justru yang lebih ditingkatkan adalah pembinaan narapidana sehingga kepentingan korban tambah tenggelam dan semakin jauh. ${ }^{2}$

Kejahatan seksual merupakan realitas yang hadir dalam kehidupan kita. Perkembangan yang terjadi memperlihatkan bahwa pelaku kejahatan seksual cenderung menjadikan anak-anak sebagai korbannya, terbukti prevalensi anak yang menjadi korban semakin tinggi dibandingkan dengan orang dewasa. Di tengah perkembangan situasi semacam ini, peraturan perundangan yang digunakan dalam proses penyelesaian hukum tidak mampu menjamin perlindungan hukum terhadap anak dari kejahatan seksual dan tidak mencerminkan keadilan bagi anak.

Berkaitan uraian diatas, maka penulis tertarik untuk membahas tentang perlindungan hukum terhadap anak korban kejahatan seksual dalam perspektif hukum positif dan Islam.

\section{B. PEMBAHASAN}

1. Perlindungan Hukum Terhadap Anak Korban Kejahatan Seksual Dalam Perspektif Hukum Positif 
Anak sebagai generasi penerus bangsa memiliki peran penting dalam pembangunan nasional wajib mendapatkan perlindungan dari negara sesuai dengan ketentuan Undang-Undang Dasar Negara Republik Indonesia Tahun 1945 yang menyatakan bahwa anak berhak atas perlindungan dari kekerasan. Pesatnya arus globalisasi dan dampak negatif dari perkembangan di bidang teknologi informasi dan komunikasi, memunculkan fenomena baru kejahatan seksual terhadap anak. Kejahatan seksual terhadap anak merupakan kejahatan serius (serious crimes) yang semakin meningkat dari waktu ke waktu dan secara signifikan mengancam dan membahayakan jiwa anak, merusak kehidupan pribadi dan tumbuh kembang anak, serta mengganggu rasa kenyamanan, ketentraman, keamanan, dan ketertiban masyarakat. Undang-Undang Nomor 23 Tahun 2002 tentang Perlindungan Anak sebagaimana telah diubah dengan Undang-Undang Nomor 35 Tahun 2014 tentang Perubahan atas UndangUndang Nomor 23 Tahun 2002 tentang Perlindungan Anak telah mengatur sanksi pidana bagi pelaku kekerasan seksual terhadap anak namun penjatuhan pidana tersebut belum memberikan efek jera dan belum mampu mencegah secara komprehensif terjadinya kekerasan seksual terhadap anak. Untuk mengatasi fenomena kekerasan seksual terhadap anak, memberi efek jera terhadap pelaku, dan mencegah terjadinya kekerasan seksual terhadap anak, Pemerintah perlu menambah pidana pokok berupa pidana mati dan pidana seumur hidup, serta pidana tambahan berupa pengumuman identitas pelaku. Selain itu, perlu menambahkan ketentuan mengenai tindakan berupa kebiri kimia, pemasangan alat pendeteksi elektronik, dan rehabilitasi.

Mukadimah Deklarasi PBB tersirat bahwa umat manusia berkewajiban memberikan yang terbaik bagi anak-anak. Semua pihak menyetujui peran anak (role of the child) merupakan harapan masa depan. Ketentuan Undang-undang tentang perlindungan hukum dimuat dalam Pasal 34 UUD 1945, ketentuan ini ditegaskan pengaturannya dengan dikeluarkannya Undang-Undang No. 4 Tahun 1979 Tentang Kesejahteraan Anak dan Undang-Undang No. 23 Tahun 2002 tentang Perlindungan Anak yang telah diperbaharui dengan Undang-Undang No. 35 Tahun 2014 
Tentang Perubahan Atas UndangUndang No. 23 Tahun 2002 tentang Perlindungan Anak dan yang terakhir Pemerintah mengeluarkan Pemerintah Pengganti Undang-Undang Nomor 1 Tahun 2016 Tentang Perubahan Kedua Atas Undang-Undang Nomor 23 Tahun 2002 Tentang Perlindungan Anak.

Secara garis besar Deklarasi Mukadimah PBB memuat 10 asas tentang hak-hak anak, yaitu: hak untuk memperoleh perlindungan khusus, kesempatan dan fasilitas yang memungkinkan mereka berkembang secara sehat dan wajar dalam keadaan bebas dan bermanfaat, memiliki nama dan kebangsaan sejak lahir, mendapat jaminan sosial termasuk gizi yang cukup, perumahan, rekreasi dan pelayanan kesehatan, memperoleh pendidikan, perawatan dan perlakuan khusus jika mereka cacat, tumbuh dan dibesarkan dalam suasana yang penuh kasih dan rasa aman sedapat mungkin di bawah asuhan serta tanggung jawab orangtua mereka sendiri mendapat pendidikan, dan dalam hal terjadi kecelakaan/malapetaka, mereka termasuk yang pertama memperoleh perlindungan terhadap segala bentuk yang menyia-nyiakan anak, kekejaman dan penindasan serta perbuatan yang mengarah ke dalam bentuk diskriminasi.

Mengingat pentingnya menjaga dan melindungi anak, pada tanggal 20 November 1989, Majelis Umum Perserikatan Bangsa-Bangsa (PBB) telah menyetujui Konvensi Hak-hak Anak. Konsideran konvensi itu memuat pokok-pokok pikiran, pengakuan atas martabat yang melekat dan hak-hak yang sama dan tidak dapat dicabut yang dimiliki anggota keluarga manusia. Ini menjadi landasan dari kemerdekaan, keadilan dan perdamaian di seluruh dunia.

Deklarasi hak asasi manusia Perserikatan Bangsa-Bangsa menyatakan, bahwa masa kanak-kanak berhak memperoleh pemeliharaan dan bantuan khusus keluarga sebagai inti dari masyarkat dan sebagai lingkungan alami bagi pertumbuhan dan kesejahteraan seluruh anggotanya dan khususnya anak-anak hendaknya diberi perlindungan dan bantuan yang diperlukan, sehingga mampu mengemban tanggung jawab dalam masyarakat.

Deklarasi PBB mengakui, bahwa di semua negara di dunia ada anak-anak yang hidup dalam keadaan sulit dan membutuhkan perhatian khusus. Untuk perlindungan anak yang serasi, perlu memperhatikan 
nilai-nilai tradisi dan budaya dan setiap bangsa. Oleh karena itu penting dilakukan kerja sama internasional untuk meningkatkan kondisi kehidupan anak di setiap negara, khususnya negara-negara berkembang.

Konvensi Hak Anak tahun 1989 yang disepakati dalam sidang Majelis Umum (General Assembly) PBB ke-44, yang selanjutnya telah dituangkan dalam Resolusi PBB Nomor 44/25 tanggal 5 Desember 1989. Konvensi Hak Anak ini merupakan hukum internasional yang mengikat negara peserta (state parties), termasuk Indonesia.

Berdasarkan materi hukum yang tercakup di dalam Konvensi Hak Anak, dapat dikualifikasikan beberapa isi konvensi, yaitu: ${ }^{3}$

1) Penegasan hak-hak anak;

2) Perlindungan anak oleh negara;

3) Peran serta berbagai pihak (pemerintah, masyarakat, dan swasta) dalam

\footnotetext{
${ }^{3}$ Paulus Hadisuprapto, Peranan Orangtua dalam Mengimplementasikan Hak-hak Anak dan Kebijakan Penanganan Anak Bermasalah, dalam Jurnal Pembangunan Kesejahteraan Sosial, Jakarta: Dewan Nasional Indonesia untuk Kesejahteraan Sosial, Nomor 7, Maret 1996, hlm. 35.
}

menjamin penghormatan terhadap hak-hak anak.

Adapun Hak Asasi Anak menurut Undang-Undang Nomor 39 Tahun 1999, meliputi:

1) Anak mendapat perlindungan orang tua, masyarakat dan negara (Pasal 62 ayat (1)).

2) Hak dilindungi sejak dan dalam kandungan (Pasal 52 ayat (1).

3) Hak hidup dan meningkatkan taraf kehidupan (Pasal 53 ayat (1).

4) Hak mendapat nama dan status kewarganegaraan (Pasal 53 ayat (2)).

5) Hak mendapat perawatan, pendidikan, pelatihan dan bantuan khusus anak cacat tisik atau mental (Pasal 54).

6) Hak untuk beribadah menurut agamanya, berpikir dan ber ekspresi (Pasal 55).

7) Hak mengetahui, dibesarkan dan diketahui orang tuanya (Pasal 56 ayat (1)). 
8) Hak diasuh dan diangkat anak oleh orang lain (Pasal 56 ayat (2)).

9) Hak dibesarkan, dipelihara, dirawat, dididik, diarahkan dan dibimbing orang tua/wali (Pasal 57 ayat (1)).

10) Hak mendapatkan orang tua angkat atau wali (Pasal 57 ayat(2)).

11) Hak perlindungan hukum (Pasal 58 at (1)).

12) Hak pemberatan hukuman bagi orang tua, wali/pengasuh yang menganiaya anak (fisik, mental, penelantaran, perlakuan buruk dan pelecehan seksual dan pembunuhan (Pasal 58 ayat (2)).

13) Hak tidak dipisahkan dari orang tua (Pasal 59 ayat (1)).

14) Hak bertemu dengan orang tua (Pasal 59 ayat (2)).

15) Hak memperoleh pendidikan dan pengajaran (Pasal 60 ayat (1)).
16) Hak mencari, menerima dan memberikan informasi (Pasal 60 ayat (2)).

17) Hak untuk beristirahat, bergaul dengan anak sebaya, bermain, berekreasi (Pasal 62).

18) Hak memperoleh pelayanan kesehatan dan jaminan sosial (Pasal 62).

19) Hak tidak dilibatkan dalam peperangan, sengketa bersenjata, kerusuhan sosial dan peristiwa kekerasan (Pasal 63).

20) Hak perlindungan dari eksploitasi ekonomi dan pekerjaan yang membahayakan dirinya (Pasal 64)

21) Hak perlindungan dan kegiatan eksploitasi dan pelecehan seksual, penculikan, perdagangan dan dan penyalahgunaan narkotika, psikotropika zat adiktif' lainnya (Pasal 65).

22) Hak tidak dijadikan sasaran penganiayaan, penyiksaan, atau penjatuhan hukuman 
yang tidak manusiawi

(Pasal 66 ayat (1)).

23) Hak tidak dapat dijatuhi hukuman mati atau hukuman seumur hidup (Pasal 66 ayat (2)).

24) Hak tidak dirampas kemerdekaannya secara melawan hukum (Pasal 66 ayat (3)).

25) Hak penangkapan, penahanan atau pidana penjara hanya sebagai upaya terakhir (Pasal 66 ayat (4)).

26) Hak perlakuan yang manusiawi bagi anak yang dirampas kemerdekaannya dan dipisahkan dan orang dewasa (Pasal 66 ayat (5)).

27) Hak bantuan hukum dan bantuan lainnya secara efektif bagi anak yang dirampas kebebasannya (Pasal 66 ayat (6)).

28) Hak membela diri dan memperoleh keadilan bagi anak yang dirampas kebebasannya di depan pengadilan yang objektif, tidak memihak dan sidang tertutup untuk umum.

Pengertian perlindungan anak (Pasal 1 angka 2 UU No. 23 Tahun 2002) adalah segala kegiatan untuk menjamin dan melindungi anak dan hak-haknya agar dapat hidüp, tumbuh, berkembang, dan berpartisipasi secara optimal sesuai dengan harkat dan martabat kemanusiaan, serta mendapat perlindungan dan kekerasan dan diskriminasi. Secara singkat ditegaskan bahwa anak-anak harus dibesarkan dalam semangat/jiwa yang penuh pengertian, toleransi, persahabatan antar bangsa, perdamaian dan persaudaraan yang bersifat universal.

Secara garis besar perlindungan anak dapat dibedakan dalam dua pengertian, yaitu:

1) Perlindungan yang bersifat yuridis meliputi:

a) bidang hukum publik; dan

b) bidang hukum keperdataan

2) Perlindungan yang bersifat non yuridis:

a) bidang sosial;

b) bidang kesehatan; dan 
c) bidang pendidikan.

Bidang yuridis menyangkut semua aturan hukum yang mempunyai dampak langsung bagi kehidupan seorang anak dalam semua aturan hukum mengatur kehidupan anak.

Di Indonesia masih berlaku baik hukum tertulis maupun hukum tidak tertulis sehingga perlindungan anak termasuk juga ketentuanketentuan hukum adat.

Pengertian Perlindungan Anak Menurut UU No. 4 Tahun 1979 tentang Kesejahteraan Anak adalah sebagai berikut:

1) Segala daya upaya yang dilakukan secara sadar oleh setiap orang maupun lembaga pemerintah, swasta yang bertujuan mengusahakan

pengamanan, penguasaan dan pemenuhan kesejahteraan fisik, mental dan sosial anak dan remaja yang sesuai dengan kepentingan hak asasinya.

2) Segala daya upaya bersama yang dilakukan dengan sadar oleh perorangan, keluarga, masyarakat, badan-badan pemerintah dan swasta untuk pengamanan, pengadaan dan pemenuhan kesejahteraan rohaniah dan jasmaniah anak berusia 021 tahun tidak dan belum pernah menikah sesuai dengan hak asasi dan kepentingannya agar dapat mengembangkan dirinya seoptimal mungkin.

Hukum perlindungan anak sebagai hukum tertulis maupun tidak tertulis yang menjamin anak benarbenar dapat melaksanakan hak dan kewajibannya. Pada tahun 1979 dikeluarkan Undang-Undang Nomor 4 Tahun 1979 tentang Kesejahteraan Anak.

Anak telah menjadi perhatian khusus bagi banyak kalangan tidak hanya di tingkatan nasional, pada dataran global, anak mendapatkan porsi khusus dalam hal perlindungan dan pemenuhan serta pengaturan hakhak mereka. Hal ini telah lama berlangsung, mengingat anak merupakan tunas dan penerus generasi kehidupan bangsa dan negara.

Dalam untuk mencapai tujuan penyelenggaraan perlindungan anak sebagaimana dimaksud dalam Undang-undang Nomor 23 Tahun 2002 tentang Perlindungan Anak diperlukan kerja sama antara 
pemerintah dan masyarakat secara melembaga, oleh karena itu dalam rangka melaksanakan ketentuan Pasal 75 ayat (4) Undang-undang Nomor 23 Tahun 2002 tentang Perlindungan Anak, dipandang perlu membentuk Komisi Perlindungan Anak Indonesia.

Adapun yang dimaksud dengan Komisi Perlindungan Anak Indonesia adalah lembaga yang bersifat independen yang dibentuk berdasarkan Undang-undang Nomor 23 Tahun 2002 tentang Perlindungan Anak dalam rangka meningkatkan efektifitas penyelenggaraan perlindungan anak. Komisi Perlindungan Anak Indonesia berkedudukan di Ibukota Negara Kesatuan Republik Indonesia.

Komisi Perlindungan Anak Indonesia mempunyai tugas:

1) melakukan sosialisasi seluruh ketentuan peraturan perundang-undangan yang berkaitan dengan perlindungan anak, mengumpulkan data dan informasi, menerima pengaduan masyarakat, melakukan penelaahan, pemantauan, evaluasi, dan pengawasan terhadap penyelenggaraan

perlindungan anak;

2) memberikan laporan, saran, masukan, dan pertimbangan kepada Presiden dalam rangka perlindungan anak.

Keanggotaan Komisi Perlindungan Anak Indonesia sebagaimana dimaksud dalam Pasal 4 terdiri dari unsur:

1) pemerintah;

2) tokoh agama;

3) tokoh masyarakat;

4) organisasi sosial;

5) organisasi kemasyarakatan;

6) organisasi profesi;

7) lembaga swadaya masyarakat;

8) dunia usaha; dan

9) kelompok masyarakat yang peduli terhadap perlindungan anak.

\section{Perlindungan Hukum Terhadap} Anak Korban Kejahatan Seksual Dalam Perspektif Hukum Islam

Islam hadir atas prinsipprinsip kemanusiaan, terutama: 
Penghormatan atas Martabat

Manusia, Kesetaraan, Kebebasaan

dan Keadilan. Islam menegaskan

prinsip-prinsip tersebut adalah :

1. Manusia adalah makhluk terhormat: "Dan sesungguhnya telah Kami muliakan anak-anak Adam, Kami angkut mereka di daratan dan di lautan, Kami beri mereka rezeki dari yang baik-baik dan Kami lebihkan mereka dengan kelebihan yang sempurna atas kebanyakan makhluk yang telah Kami ciptakan". (Q.S. Al-Isra, [17]:70).

2. Laki-laki dan Perempuan adalah Setara: (Q.S. Q.S. al-Nisa, [4:1), , a.1. Q.S. al-Ahzab, 53:35, alTaubah, 71, al-Nahl, 97, Ali Imran,[3]: 195 dan al-Mukmin, 40.

3. Manusia yang paling terhormat/unggul adalah yang paling bertaqwa: "Hai manusia, sesungguhnya Kami menciptakan kamu dari seorang laki-laki dan seorang perempuan dan menjadikan kamu berbangsabangsa dan bersuku-suku supaya kamu saling kenal mengenal. Sesungguhnya orang yang paling mulia di antara kamu di sisi Allah ialah orang yang paling bertakwa di antara kamu. Sesungguhnya Allah Maha Mengetahui lagi Maha
Mengenal”. (Q.S. Al-Hujurat, [49]:12).

4. "Hai orang-orang yang beriman, janganlah komunitas laki-laki merendahkan komunitas yang lain, boleh jadi yang direndahkan itu lebih baik dari mereka yang merendahkan. Dan jangan pula komunitas perempuan merendahkan komunitas perempuan yang lain, boleh jadi yang direndahkan itu lebih baik. Dan janganlah suka mencela dirimu sendiri dan jangan memanggil dengan panggilan yang mengandung pelecehan. Sikap dan tindakan merendahkan dan melecehkan itu adalah perilaku yang buruk dari seorang yang telah beriman. Barangsiapa yang tidak kembali memperbaiki diri maka mereka itulah orang-orang yang zalim".(Q.S. al-Hujurat [49]:11).

Tindak pidana kekerasan seksual terhadap anak merupakan salah satu bentuk kekerasan yang sangat merugikan korban. Kekerasan, pelecehan, dan eksploitasi seksual itu bukan hanya menimpa perempuan dewasa, namun juga perempuan yang tergolong di bawah umur (anakanak). Kejahatan seksual ini juga tidak hanya berlangsung di 
lingkungan perusahaan, perkantoran atau di tempat-tempat tertentu yang memberikan peluang manusia berlainan jenis dapat saling berkomunikasi, namun juga dapat terjadi di lingkungan keluarga. Gerakan feminisme akhir-akhir ini merambah dan menggugat wilayah hukum positif, yang menurutnya, aspek pelaksanaannya belum mencerminkan, mewakili, memberikan jawaban, dan meresponsi keadilan penderita (korban perkosaan) atau masih lebih sering berpihak pada kepentingan kaum laki-laki, dan belum menempatkan asas kesamaan hukum (equality before the law) sebagai suatu kekuatan moral-yuridis, sosial dan psikologis guna melindungi hakhak kaum perempuan. Kelompok feminis itu berasumsi kalau kaum perempuan di mata hukum masih menjadi kelompok marjinal atau berposisi sebagai pihak yang dikorbankan oleh praktek hukum di Indonesia.

Dalam perspektif Islam aspek hukum pidana materil ini menyangkut soal suatu perbuatan yang berdasarkan syari'at yang telah ditetapkan sebagai suatu tindak pidana. Pembuat hukum, dalam hal ini Allah SWT telah menggariskan berbagai jenis perbuatan (kejahatan) dikategorikan sebagai tindak pidana, seperti pencurian, penganiayaan, makar, pembunuhan, dan perkosaan (kekerasan seksual). Pijakan atas larangan melakukan perzinahan adalah Qur'an Surat Al-Israa' ayat 32 : "Dan janganlah kamu mendekati zina; sesungguhnya zina itu adalah suatu perbuatan yang keji dan suatu jalan yang buruk".

Larangan dalam ayat ini menunjukkan suatu peringatan yang keras. Peringatan ini berkaitan dengan keharaman berbuat zina. Sebelum sampai pada jenis perbuatan yang sebenarnya (zina), Allah SWT sudah melarangnya. Baru pada tahap hendak "berdekatan" dengan perbuatan tersebut, atau berhubungan dengan faktor-faktor yang dapat mempengaruhi dan menjebak seseorang ke dalam perbuatan keji itu, Allah SWT sudah melarangnya dengan keras.

Mayoritas ulama telah berpendapat bahwa dalam kasus perkosaan, pihak pelaku dapat 
ditempatkan (diposisikan) status hukumnya dengan pezina, sedangkan pihak korban status hukumnya menjadi seseorang yang terpaksa berhubungan seks atau berbuat sesuatu di luar kehendaknya. Ada upaya keras dan terkadang sistematik yang dilakukan oleh pelaku terhadap korban. Pihak korban dibuatnya tidak berdaya, sehingga dapat dijadikan sarana melampiaskan nafsu bejatnya. Korban ditempatkan layaknya sebagai alat dan objek untuk memenuhi hajat pelaku. Sedangkan pelaku dapat berbuat sekehendaknya yang jelasjelas tidak mengindahkan hak-hak asasi korban. ${ }^{4}$

$$
\text { Dengan adanya }
$$

pemahaman demikian itu, maka setidak-tidaknya proses penyelesaian hukum dan penjatuhan sanksi hukumannya kepada pelaku perkosaan dapat berpijak pada proses penyelesaian dan sanksi hukuman yang dikenakan pada kasus perzinahan, artinya standar yang digunakan adalah standar minimal, dan bukan mengacu secara mutlak terhadap

\footnotetext{
${ }^{4}$ Baharuddin Lopa, Seri Tafsir Al-Qur'an Bil-Ilmi 03, Al-Qur'an dan Hak-hak Asasi Manusia, Bhakti Prima Yasa, Yogyakarta, 1996, hlm 1
}

kasus perzinahan, khususnya dalam hal penjatuhan sanksi hukumnya. ${ }^{5}$

Secara substansi materiilnya, perkosaan juga mengandung unsur perzinahan, yakni suatu jenis persetubuhan di luar perkawinan yang sah, dengan catatan perbuatan itu tidak didasari suka sama suka, melainkan atas dasar paksaan. Faktor paksaan dan kekerasan yang mendukung keberhasilan perbuatan itulah yang harus dijadikan acuan bahwa perbuatan itu melebihi kasus perzinahan.

Perkosaan hanya merupakan wujud kebutuhan sepihak atau dari pihak pemerkosanya, sedangkan bagi yang diperkosa, kekerasan itu membuat dirinya menderita secara psikis maupun fisik. Dalam perzinahan, derita seperti ini tidak dirasakan secara langsung oleh pihak yang melakukannya, sedangkan dalam kasus perkosaan, pihak korbannya mengalami derita tiada tara.

Dalam pandangan Hukum Islam, tindak pidana kekerasan seksual merupakan perbuatan yang dilarang. Perbuatan yang dilarang

\section{${ }^{5}$ Ibid}


ini disebut juga dengan jarimah.

Jarimah merupakan laranganlarangan Syara' yang diancamkan oleh Allah dengan hukuman had atau ta'zir. ${ }^{6}$ Kerugian ini dapat berupa rasa trauma atau rasa malu kepada keluarga atau masyarakat. Akibat jarimah perkosaan (zina) dibagi dua, yaitu: Jika pelaku masih bujang, maka ia dikenai hukuman had dengan hukuman dicambuk/dera 100 (seratus) kali dan pengasingan (ada yang menafsirkan diusir ke luar daerah). Jika pelaku telah beristri atau bersuami, maka hukumannya adalah dirajam atau dilempari batu sampai meninggal dunia. Adapun perbedaan antara hukuman zina dengan hukuman terhadap tindak pidana pemerkosaan adalah, bahwa hukuman zina dikenakan kepada kedua belah pihak (lakilaki dan perempuan) sedangkan untuk hukuman perkosaan dikenakan kepada pelakunya.

Rasulullah sendiri, ketika dihadapkan kepadanya pria dan wanita mukhson yang berzina, beliau menghukumnya dengan

6 Taufan Symposion, Kekerasan Terhadap Anak Menurut Hukum Positif Dan Menurut Hukum Islam, informasimayazar.blogspot.com, diakses tanggal 14 Juni 2017 jam 16.00 WIB merajam. Penegasan ini masih disepakati para sahabat, tabi'in, dan para ulama dan fuqaha Islam. Tidak satupun dari mereka yang meragukan hukum rajam sebagai hukum syari'at yang tetap sesuai dengan dalil-dalil sunnah yang kuat lagi shahih. Ibnu Taimiyah juga menegaskan, bahwa pelaku zina mukhson dirajam hingga mati, sebagaimana yang dilakukan Nabi SAW terhadap Maiz bin Malik AlAslami. Beliau juga pernah merajam wanita Ghamid, dan lain sebagainya. $^{7}$

Jenis hukuman yang dijatuhkan berkaitan dengan pelaku zina itu juga diikuti oleh penguasa sesudah Nabi Muhammad SAW. Misalnya di zaman pemerintahan Umar bin Khattab, juga terjadi penerapan hukuman cambuk dan rajam sehingga sampai meninggal dunia. Bahkan Khalifah Umar bin Khattab menjatuhi hukuman cambuk kepada anaknya bernama Ubaidillah atau Abi Syamsah, yang telah melakukan perzinahan hingga Abi Syamsah meninggal

\footnotetext{
7 Ibnu Taimiyah, As-Siyasah AsySyar'iyyah fil Ishlahir Raa'iwar Ra'iyah, Terjemahan Muhammad Munawwir, (Kebijakan Politik Nabi SAW), Dunia Ilmu, Surabaya, 1997, halaman 100
} 
dunia. Lalu Khafilah membawanya

kerumahnya, memandikannya dan menguburkannya. ${ }^{8}$

\section{Kesimpulan}

Berdasarkan uraian diatas dengan mengacu pada teori hukum yang dikaitkan dengan fakta kejadian yang ada dapat simpulan sebagai berikut:

Perlindungan hukum bagi anak sebagai korban tindak pidana kekerasan seksual dalam UndangUndang Perlindungan Anak sifatnya hanya mengatur perbuatan melawan hukum dari si pelaku yang dilihat dari unsur dan ancaman pasal pidana yang cukup tinggi dan ditambah dengan pidana denda, yang tentunya cukup membuat pelaku tindak pidana kekerasan seksual akan menjadi jera, namun Undang-Undang Perlindungan Anak tersebut belum sepenuhnya memberikan perlindungan hukum bagi anak sebagai korban. Perlindungan khusus kepada anak diatur di dalam Pasal 59 ayat (1) Undang-Undang Nomor 35 Tahun 2014 tentang Perlindungan Anak yang berbunyi pemerintah, pemerintah daerah dan lembaga negara lainnya berkewajiban dan bertanggung jawab untuk memberikan perlindungan khusus

${ }^{8}$ Abdur Rahman, Tindak Pidana dalam Syari'at Islam, (terjemahan Wadi Masturi), Rineka Cipta, Jakarta, 1992, hlm 38-39 terhadap anak, tetapi di dalam prakteknya pemerintah daerah tidak peduli dengan kondisi korban karena di dalam persidangan menurut keterangan dari korban sendiri tidak ada perlindungan dari lembaga manapun terhadap korban kekerasan seksual tersebut. Perlindungan hukum terhadap anak sebagai korban tindak pidana kekerasan seksual belum dilaksanakan secara efektif dan optimal, ditiap-tiap daerah belum ada lembaga perlindungan korban tindak pidana kekerasan seksual atau suatu lembaga atau tim atau wadah yang tugasnya melaksanakan sosialisasi, pemantauan, pengawasan, penyuluhan yang saling berkoordinasi dengan aparat penegak hukum, yang sifatnya jemput bola.

Kasus perkosaan (kejahatan seksual) khususnya pada anak, pihak pelaku dapat ditempatkan (diposisikan) status hukumnya dengan pezina, sedangkan pihak korban status hukumnya menjadi seseorang yang terpaksa berhubungan seks atau berbuat sesuatu di luar kehendaknya. Adapun perbedaan antara hukuman zina dengan hukuman terhadap tindak pidana pemerkosaan adalah, bahwa hukuman zina dikenakan kepada kedua belah pihak (laki-laki dan perempuan) sedangkan untuk 
hukuman perkosaan dikenakan kepada pelakunya.

\section{Daftar Pustaka}

Abdur Rahman, Tindak Pidana dalam Syari'at Islam, (terjemahan Wadi Masturi), Rineka Cipta, Jakarta, 1992

Baharuddin Lopa, Seri Tafsir AlQur'an Bil-Ilmi 03, Al-Qur'an dan Hak-hak Asasi Manusia, Bhakti Prima Yasa, Yogyakarta, 1996

Hardius Usman dan Nachrowi Djalal Nachrowi, Pekerja Anak di Indonesia: Kondisi, Determinan dan Eksploitasi (Jakarta: Grasindo, 2004)

Ibnu Taimiyah, As-Siyasah AsySyar'iyyah fil Ishlahir Raa'iwar Ra'iyah,

Terjemahan Muhammad Munawwir, (Kebijakan Politik Nabi SAW), Dunia Ilmu, Surabaya, 1997

Paulus Hadisuprapto, Peranan Orangtua dalam Mengimplementasikan Hakhak Anak dan Kebijakan Penanganan Anak Bermasalah, dalam Jurnal Pembangunan Kesejahteraan Sosial, Jakarta: Dewan Nasional Indonesia untuk Kesejahteraan Sosial, Nomor 7, Maret 1996

Taufan Symposion , Kekerasan Terhadap Anak Menurut Hukum Positif Dan Menurut Hukum Islam, informasimayazar.blogspot.co $m$, diakses tanggal 14 Juni 2017 jam 16.00 WIB

\section{Undang-Undang Dasar 1945 Amandemen Kedua \\ Undang-Undang No. 4 Tahun 1979 Tentang Kesejahteraan Anak \\ Undang-Undang Nomor 39 Tahun 1999 Tentang Hak Asasi Manusia \\ Undang-undang Nomor 23 Tahun 2002 tentang Perlindungan Anak \\ Undang-undang Nomor 35 Tahun 2014 tentang Perubahan atas Undang-Undang Nomor 23 Tahun 2002}

Pemerintah Pengganti UndangUndang Nomor 1 Tahun 2016 